\title{
Microbial Mat Boundaries between Chemolithotrophs and Phototrophs in Geothermal Hot Spring Effluents
}

\section{Kenji Kato*}

Institute of Geoscience, School of Science,

Shizuoka University, Shizuoka 422-8529, Japan

\section{Takeshi Kobayashi}

Laboratory of Environmental Science and Microbiology,

Graduate School of Pharmaceutical Sciences, Osaka University,

Suita 565-0871, Japan

\section{Hiroyuki Yamamoto}

Japan Marine Science and Technology Center, Yokosuka, 237-0061, Japan

\section{Takkou Nakagawa}

Department of Biology, Faculty of Science, Tokyo Metropolitan University, Hachio-ji 192-0397, Japan

\section{Yonosuke Maki}

Laboratory of Biology, Faculty of Humanities and Social Sciences, Iwate University, Morioka 020-8550, Japan

\section{Toshihiro Hoaki}

Biotechnology Section

Taisei Corporation Research Center

Yokohama, Kanagawa, Japan

* Corresponding author. Mailing address: Institute of Geoscience, School of Science, Shizuoka University, 836 Oya, Shizuoka 422-8529, Japan.

Phone \& Fax: +81-54-238-4950. E-mail: skkato@ipc.shizuoka.ac.jp.

Running head: Boundaries between Chemolithotrophs and Phototrophs 


\begin{abstract}
Among the various microbial mats that develop in geothermal hot springs in solfataric fields, colorless sulfur-turf (ST) - macroscopic white bundles consisting of large sickle-shaped bacteria belonging to Aquificales and elemental sulfur particles develops in a limited environment of geothermal effluent containing hydrogen sulfide with neutral $\mathrm{pH}$ and low in oxygen. Photosynthetic cyanobacterial mat $(\mathrm{CY})$ often grow just downstream of chemolithotrophic ST, or they coexist with ST where the temperature is slightly lower. Knowledge of the environmental regimes of these microbial mats will lead to better understanding of the distribution of thermophilic microorganisms on the Earth and provide clues about evolutionary processes in the microbial ecosystems of the Precambrian era.

We studied the environmental parameters of the boundary zone and examined the distribution of these types of mats and measured the in situ growth rates of the microorganisms composing them. In situ examination revealed that temperature and Eh constrain the development of the microbial mats. At the boundary between ST and CY, temperature and Eh ranged between $51.1^{\circ} \mathrm{C}$ and $63.2^{\circ} \mathrm{C}$ and between $-112 \mathrm{mV}$ and -25 $\mathrm{mV}$, respectively. These environmental parameters were not significantly different among Japanese, Yellowstone (North American), and Icelandic hot spring effluents with genetically similar thermal sulfur oxidizers. Sickle-shaped bacteria rarely coexist with cyanobacteria, although they can potentially grow in some CY environments. This suggests that the boundary between ST and CY might be partly determined by exclusive ecological competition.
\end{abstract}

Key words: boundary, chemolithotroph, cyanobacterial mat, hot spring, oxidation-reduction potential, phototroph, sulfur-turf, temperature gradien 


\section{Introduction}

If geothermal hot spring effluent contains some amount of hydrogen sulfide and less than 1-2 $\mathrm{mg} / \mathrm{L}$ dissolved oxygen, a conspicuously white feather-like microbial mat called sulfur-turf (ST) often develops in the effluent at temperatures above about $60{ }^{\circ} \mathrm{C}$ and with neutral $\mathrm{pH}$, as was suggested by Maki (1991). There are relatively few descriptions of colorless sulfur bacterial mats or streamers in hydrogen sulfide-rich hot springs (Reysenbach et al. 1994, Skirnisdottir et al. 2000), although various photosynthetic bacterial mats in geothermal environments are well studied (Castenholtz 1976, Ferris et al. 1996, Ferris and Ward 1997, Hugenholtz et al. 1998, Ward et al. 1998, Ramsing et al. 2000). Previous studies have characterized the physiological and ecological features of the constituents of ST (Maki 1987a, 1987b, 1993), but the large sickle-shaped bacteria that predominate in ST remain uncultivated. Maki (1987b) showed that the microorganisms constituting ST chemolithotrophically oxidize sulfide to elemental sulfur, and then oxidize elemental sulfur to sulfate via thiosulfate. The $16 \mathrm{~S}$ rRNA gene sequence from ST mats suggests that this large sickle-shaped bacterium belongs to the order Aquificales, which are deeply branching bacteria on the 16S rRNA phylogenetic tree (Yamamoto et al. 1998).

Hot spring effluent also provides habitats for various photosynthetic prokaryotes, including cyanobacteria and Chloroflexus, when light is available, (Castenholtz 1976, Ward et al. 1998, Hiraishi et al. 1999). If the temperature is less than about $60{ }^{\circ} \mathrm{C}$, photosynthetic bacteria construct green, orange, olive-green, or purple microbial mats in the hot springs so far examined in Japan.

ST and photosynthetic bacterial mats often develop along a thermal gradient of the effluent of a geothermal hot spring. These microbial mats are usually in contact with each other, but the boundaries between them are distinct, in particular in the Japanese hot springs that have been examined (Fig. 1). Thus, a marked change in the trophic dynamics of microbial communities is noticeable along the temperature gradient of hot 
spring effluents.

Microorganisms that obtain energy chemolithotrophically, such as Aquificales, are considered to have composed the first ecosystems on the early Earth, before the appearance of the photosynthetic bacteria, although what electron acceptor was available in the ancient atmosphere is still uncertain (see Vargas et al. 1998). Subsequently, the sustaining energy machinery of the ecosystem evolved from chemotroph to phototroph. In support of this, the 16S rRNA gene-based phylogeny shows that Aquificales and related bacterial strains that predominate in sulfur-rich hot springs are more deeply branching than the photosynthetic bacteria (Knoll 1999). It is quite likely that ST and other colorless mats in sulfide-rich hot springs preserve an ancient ecological feature (Reysenbach and Cady 2001). Thus, it is exciting to examine where and how ST develops and how it affects or is affected by the development of photosynthetic bacterial mats nearby.

Little is known about the environmental factors that determine the boundary between such colorless sulfur mats and photosynthetic bacterial mats. Thus, we examined the distribution pattern of ST microbial mats by measuring environmental parameters and estimating the in situ growth rate of the sickle-shaped bacteria in neutral hydrogen sulfide-rich hot spring effluent to reveal the mechanism by which the boundaries between microbial mats are determined. The field survey was extended to Yellowstone National Park in 1999 and 2000 to compare environmental constraints on the growth of genetically related thermal sulfur oxidizers.

\section{Materials and Methods}

Research Sites

We examined three geographically isolated hot springs located in Nagano prefecture, Japan: Nakabusa [lat $36^{\circ} 23^{\prime} \mathrm{N}$, long $137^{\circ} 45^{\prime} \mathrm{E}, 1390 \mathrm{~m}$ above sea level (ASL)], Nakanoyu (lat $36^{\circ} 11^{\prime} \mathrm{N}$, long $137^{\circ} 37^{\prime} \mathrm{E}, 1300 \mathrm{~m} \mathrm{ASL}$ ), and Yumata (lat $36^{\circ} 24^{\prime} \mathrm{N}$, long 
$\left.137^{\circ} 41^{\prime} \mathrm{E}, 1430 \mathrm{~m} \mathrm{ASL}\right)$. Geothermal microbial mats have developed on the rocks at Nakanoyu and in the riverbed at Yumata. At Nakabusa, the effluent flows down the concrete wall of a dam, and the microbial mats have developed separately along small hot-water streams issuing from cracks in the dam (Sugiura et al. 2001). The field experiment in Yellowstone National Park was carried out in a pool near Fire Hole Lake (lat $44^{\circ} 32^{\prime} \mathrm{N}$, long $110^{\circ} 47^{\prime} \mathrm{W}$ ) and at Tangerine Mound and Bath Lake Vista of Mammoth Springs (lat 445' $51^{\prime \prime N}$, long $110^{\circ} 42^{\prime} 45^{\prime \prime} \mathrm{W}$ ).

\section{In Situ Examination}

Environmental parameters were examined by using the following digital meters: a digital thermometer with a probe $3 \mathrm{~mm}$ in diameter (DIGITAL HAND-THERMO, Sanyo Co. Ltd., Osaka, Japan) for measurement of temperature, a model CM-14P electrical conductivity (EC) meter with a 10-mm-diameter probe (DKK-TOA Co. Ltd., Tokyo, Japan), a model HM-14P pH meter with a 6-mm-diameter probe (DKK-TOA Co. Ltd. Tokyo, Japan) or a model HPH-110 pH meter with a 6-mm-diameter probe (DKK-TOA Co. Ltd. Tokyo, Japan), a model RM-14P oxidation-reduction potential (ORP) meter with a 4-mm-diameter probe (DKK-TOA Co. Ltd. Tokyo, Japan), and a model DO-14P dissolved oxygen concentration (DO) meter with a 3-mm-diameter probe (DKK-TOA Co. Ltd. Tokyo, Japan) or with a 12-mm-diameter probe (MODEL 58, YSI Co., Yellow Spings, Ohio, U.S.A.). The ORP was converted to Eh using a reference electrode. The dissolved sulfide concentration of the water was measured in situ with a simple tube kit for sulfide ion (No. 211, GASTEC Co. Ltd.). Measurements of dissolved hydrogen sulfide concentration taken with the kit were compared with spectrophotometric results (Cline 1969) obtained in 2000.

The employed probes were directly immersed in the water, and we measured environmental parameters just above the mats. However, at Nakabusa hot spring, to measure $\mathrm{EC}, \mathrm{pH}, \mathrm{Eh}$, and DO, we carefully collected water from the effluent flowing 
down the wall of the dam in a jug, and then took the measurements immediately.

Collected microbial mats were separated quickly into two subsamples for microscopic observation and for measurement of the absorption spectrum. Subsamples for microscopic observation were fixed immediately with $2 \%(\mathrm{v} / \mathrm{v})$ formaldehyde neutralized with hexamethylenetetramine $\left(\left(\mathrm{CH}_{2}\right)_{6} \mathrm{~N}_{4}\right)$, and stored at room temperature until observation. Subsamples for the measurement of absorption spectra were stored in a refrigerator in the dark until measurement.

\section{Chemical Analysis of Hot Spring Effluents}

Water samples for chemical analysis were stored in $50-\mathrm{mL}$ polyethylene bottles at $-20{ }^{\circ} \mathrm{C}$ prior to analysis. $\mathrm{NO}_{2}{ }^{-}$and $\mathrm{NO}_{3}{ }^{-}$concentrations were determined by using ion chromatography (Dionex, Analyzer with Ion pack AS4A for the determination of anion, Sunny Valley, CA, U.S.A.). $\mathrm{PO}_{4}{ }^{3-}$ and $\mathrm{NH}_{4}{ }^{+}$concentrations were measured by spectrophotometry according to the method of Strickland and Parsons (1972).

\section{Microscopic and Spectroscopic Observations of Microbial Mats}

A fraction of the fixed subsamples of microbial mats were air dried on glass slides, and stained with 4',6-diamidino-2-phenylindole (DAPI; $1 \mu \mathrm{g} \mathrm{mL}^{-1}$ in distilled water filtered through a 0.22- $\mu$ m-pore-size polycarbonate membrane filter; Nuclepore Corp., Pleasanton, CA, USA). The constituents of the microbial mats were observed by epifluorescence microscopy (BX50, OLYMPUS, Tokyo, Japan) with UV excitation.

Unfixed subsamples of microbial mats were directly suspended in distilled water, and the absorption spectra were measured between $600 \mathrm{~nm}$ and $900 \mathrm{~nm}$ with a spectrophotometer (model U-3200, Hitachi Co. Ltd., Tokyo, Japan).

\section{Growth Experiment}

To estimate sickle-shaped bacterial growth at the boundary between ST and 
photosynthetic cyanobacterial mat (CY), an experiment was carried out at Nakabusa hot spring on 9, 22, and 30 October 1998. Glass slides, which had been previously sterilized in a dry oven at $120^{\circ} \mathrm{C}$ for $1 \mathrm{~h}$, were immersed in hot spring effluent. Paired glass slides were immersed for $6 \mathrm{~h}(6 \mathrm{H})$ or $12 \mathrm{~h}(12 \mathrm{H})$ in effluents where the temperature ranged from $50{ }^{\circ} \mathrm{C}$ to $60{ }^{\circ} \mathrm{C}$. Collected glass slides were dried and stored in a refrigerator $(<$ $4{ }^{\circ} \mathrm{C}$ ) in the dark until counting. Microorganisms on the slides were stained with DAPI, and cells of total microorganisms, sickle-shaped bacteria, and cyanobacteria were counted on the basis of morphological distinctions observed under an epifluorescence microscope connected to a chilled 3-chip color CCD camera (HAMAMATSU Co. Ltd., Hamamatsu, Japan) and a color image analyzer (SP500F, Olympus Co. Ltd.). The growth rate constant $(\mu)$ was estimated from the number of attached cells at $6 \mathrm{H}$ and $12 \mathrm{H}$. We estimated the attachment rate from the number of attached cells at $6 \mathrm{H}$, although in situ growth might have occurred if the doubling time was as high as $6 \mathrm{~h}$ (see Results).

\section{Results}

\section{General Description of the Hot Springs}

Physical and chemical parameters of the effluent at the source of each hot spring are shown in Table 1 . The water was hotter than $50{ }^{\circ} \mathrm{C}$ at all hot springs. Among the chemical parameters of hot spring effluent, the EC of the water differed among the three sites, ranging from $31.8 \mathrm{mS} \mathrm{m}^{-1}$ (Nakabusa) to $183.7 \mathrm{mS} \mathrm{m}^{-1}$ (Yumata). The $\mathrm{pH}$ was about neutral but differed somewhat among the three hot springs, ranging from 6.22 (Nakanoyu) to 8.44 (Nakabusa). The waters of the three hot springs contained sulfide with more than $2 \mathrm{mg} \mathrm{L}^{-1}$, measured by a simple tube kit in situ, and the concentration of dissolved oxygen (DO) was less than $1.66 \mathrm{mg} \mathrm{L}^{-1}$. The Eh of the water was less than 11 $\mathrm{mV}$ for all effluent sources. The hydrogen sulfide concentration determined by the 
spectrophotometric method ranged from 0.07 to $9.37 \mathrm{mg} \mathrm{L}^{-1}$ for the Nakabusa and Nakanoyu hot spring effluents, which was in nearly the same range as that measured previously by using the kit (Table 1). At Nakanoyu hot spring, the concentration of $\mathrm{PO}_{4}{ }^{3-}$ in the effluent ranged from $0.28 \mathrm{mg} \mathrm{L}^{-1}$ to $0.30 \mathrm{mg} \mathrm{L}^{-1}$, that of $\mathrm{NH}_{4}{ }^{+}$ranged from 0.66 to $0.70 \mathrm{mg} \mathrm{L}^{-1}$, and that of $\mathrm{NO}_{3}^{-}$was $0.08 \mathrm{mg} \mathrm{L}^{-1}$. At Nakabusa, the concentration of $\mathrm{PO}_{4}{ }^{3-}$ was $0.28 \mathrm{mg} \mathrm{L}^{-1}$, and that of $\mathrm{NH}_{4}{ }^{+}$ranged from 0.09 to $0.11 \mathrm{mg} \mathrm{L}^{-1} . \mathrm{NO}_{2}^{-}$was below detection limits in all examined hot spring effluents.

\section{Constituents of Microbial Mats}

Constituents of each microbial mat were examined spectrophotometrically and microscopically. We obtained no absorption peaks from the ST collected from $68{ }^{\circ} \mathrm{C}$ water (Fig. 2), which suggests that this ST did not contain any pigments in significant amounts. In contrast, we obtained clear absorption peaks at $680 \mathrm{~nm}$ and between 620 $\mathrm{nm}$ and $630 \mathrm{~nm}$ from $\mathrm{CY}\left(55^{\circ} \mathrm{C}\right.$ and $\left.59^{\circ} \mathrm{C}\right)$, which correspond to the absorption peaks of chlorophyll $a$ and phycocyanin, respectively. However, CY taken from the $59{ }^{\circ} \mathrm{C}$ water showed a peak for bacteriochlorophyll $c(740 \pm 2 \mathrm{~nm})$, which suggests that Chloroflexus or related green non-sulfur bacteria was present in that environment (Pierson and Castenholz 1991), and Chloroflexus sp. was observed under the microscope. We also obtained a peak at $740 \pm 2 \mathrm{~nm}$ from olive-green and orange mats (BC), which corresponds to the absorption peak of bacteriochlorophyll $c$. Two absorption peaks at a long wavelength of more than $800 \mathrm{~nm}$ were obtained from a purple mat (PM) found at Nakanoyu hot spring, which suggests the presence of 
photosynthetic bacteria other than cyanobacteria and Chloroflexus. Hanada et al. (2002) newly identified a filamentous photosynthetic bacterium from Nakabusa hot spring as Roseiflexus castenholzii gen. nov., sp. nov.; it had an optimum growth temperature of $50{ }^{\circ} \mathrm{C}$ and showed absorption peaks in vivo at $801 \mathrm{~nm}$ and $878 \mathrm{~nm}$.

Examination of the DAPI-stained samples showed that sickle-shaped bacteria with cell length from 5 to $20 \mu \mathrm{m}$ predominated in ST (Fig. 3). Unicellular and filamentous cyanobacteria about $5 \mu \mathrm{m}$ long predominated in $\mathrm{CY}$, which showed the red autofluorescence of chlorophyll $a$. Rod-shaped prokaryotic microorganisms about $2 \mu \mathrm{m}$ long predominated in $\mathrm{BC}$, and large rod-shaped prokaryotic microorganisms about $3 \mu \mathrm{m}$ long predominated in PM.

\section{Environmental Constraints of Microbial Mats}

The different microbial mats observed in this study are listed in Table 2, together with their environmental parameters. In the hot springs so far examined in Japan, both ST and CY were present; generally ST was found in hotter locations than CY, but they both could be found where temperatures ranged from $51.1^{\circ} \mathrm{C}$ to $63.2{ }^{\circ} \mathrm{C}$. $\mathrm{pH}$ was somewhat high and dissolved oxygen concentration was significantly high in environments with CY compared with those with ST, reflecting the oxygen generated by the photosynthetic activity of the cyanobacteria. The highest dissolved oxygen concentration observed when ST was present was $1.81 \mathrm{mg} \mathrm{L}^{-1}$. An increase in Eh represented oxygenation between the $\mathrm{ST}$ region and the $\mathrm{CY}$ region.

BC were found only at Yumata, where they coexisted with CY, but in areas with 
slightly lower Eh. In addition to these mats, PM were found in a limited area at Nakanoyu.

\section{Growth Experiment}

The growth rate constant $(\mu)$ of the sickle-shaped bacteria was estimated by an in situ experiment. The estimates of cell number among the counting grids often had large standard deviations, from $17 \%$ to $175 \%$, because the glass slides examined were not evenly covered by cells, and aggregates appeared often along with the pass of water on the glass slides. We counted more than 200 cells in total on $6 \mathrm{H}$ slides and more than 500 cells on $12 \mathrm{H}$ slides. Figure 4 shows the relation between the estimated $\mu$ and temperature or Eh of the in situ environment. Estimated $\mu$ tended to rise as temperature increased and Eh decreased, although in some cases no growth was found at temperatures less than $56{ }^{\circ} \mathrm{C}$, irrespective of the value of Eh. The highest $\mu$ was estimated to $0.6 \mathrm{~h}^{-1}$ (doubling time; $1.2 \mathrm{~h}$ ) at $55.2^{\circ} \mathrm{C}$ and $\mathrm{Eh}-68 \mathrm{mV}$. The result showed that sickle-shaped bacteria could grow between 50.7 and $57.7{ }^{\circ} \mathrm{C}$ and between -91 and $110 \mathrm{mV}$ Eh, although temperatures higher than $58{ }^{\circ} \mathrm{C}$ were not tested in this experiment. Although in situ ST was restricted to locations with temperature higher than $51.1^{\circ} \mathrm{C}$ and Eh lower than $-25 \mathrm{mV}$, the sickle-shaped bacteria were often shown to grow in environments exceeding these limits. Cyanobacterial cells on glass slides immersed for $12 \mathrm{~h}$ accounted for $0 \%$ to $8 \%$ of all attached microorganism cells in this experiment. 


\section{Discussion}

Yamamoto et al. (1998) demonstrated that the sickle-shaped bacterium, the major constituent of ST at all hot springs (Fig. 3), formed a major cluster with members of the Aquifex-Hydrogenobacter complex, which in turn are the most deeply branching bacteria on a phylogenetic tree based on 16S rRNA gene sequences. Maki (1991) suggested that ST develops in shallow sulfide-rich geothermal water streams with temperature ranging from $50{ }^{\circ} \mathrm{C}$ to $72{ }^{\circ} \mathrm{C}$ and $\mathrm{pH}$ between 6 and 9 . In this study, we showed that the upper limit of temperature for ST was $77.2^{\circ} \mathrm{C}$, which is slightly higher than previously reported. Although Maki (1986) reported that the maximum DO concentration at which ST was able to develop was less than $1 \mathrm{mg} \mathrm{L}^{-1}$, the maximum ambient DO concentration observed in the present study was $1.81 \mathrm{mg} \mathrm{L}^{-1}$ (Table 2).

In hot spring effluents where ST and CY coexist, CY developed downstream from ST in all effluents with temperatures lower than $63.2{ }^{\circ} \mathrm{C}$, whereas Ward et al. (1998) indicated that Synechococcus lividus formed microbial mats at an upper temperature limit of $74{ }^{\circ} \mathrm{C}$ in Yellowstone National Park, North America. The highest temperature at which cyanobacterial mat formation was found in this study of Japanese hot springs was $63.2^{\circ} \mathrm{C}$, which suggests that some other restrictive factor such as hydrogen sulfide may constrain the growth of more thermophilic cyanobacteria.

Microbial mats developed in hot spring streams displayed a stratified structure, in which the constituents of the deeper layer differed from those of the surface stratum when examined microscopically. However, we focused on the horizontal microbial distribution in this study rather than the vertical one to elucidate the environmental effect clearly, because we can easily find horizontal segregation of different types of mat in some Japanese hot springs. Thus, to examine the interactions between microbial mats and the environment in particular, we scrutinized the physico-chemical parameters at the boundaries of mats exposed to hot water effluent at their surfaces.

Figure 5 shows the distributions of the four microbial mat types (ST, CY, BC, and 
PM) for each environmental parameter vs temperature. Overlapping boundary zones between ST and CY were found within the following ranges: temperature $51.1-63.2{ }^{\circ} \mathrm{C}$; pH 7.53 and above; Eh -112 to $-25 \mathrm{mV}$, and DO $0.25-1.81 \mathrm{mg} \mathrm{L}^{-1}$. The effluents of both Nakanoyu and Nakabusa hot springs contained significant amounts of $\mathrm{PO}_{4}{ }^{3-}, \mathrm{NO}_{3}{ }^{-}$, and $\mathrm{NH}_{4}{ }^{+}$. Thus, nitrogen and phosphorus do not seem to be limiting factors in the growth of microorganisms in the mats. It is clear that water temperature regulates the development of different mats (Fig. 5A-C). The development of the mats is also closely correlated with the Eh of the environment (Fig. 5A), which suggests that Eh controls the metabolic activity of microorganisms in the mats and that it must also be affected in turn by that activity. ST was present at temperatures higher than $51.1^{\circ} \mathrm{C}$, but only in a more reductive environment, that is, at Eh less than $-75 \mathrm{mV}$; though $\mathrm{ST}$ was found together with $\mathrm{CY}$ even where the Eh was less than $-25 \mathrm{mV}$. As the procedure in construction of overlapping zone is not cleared yet, a scenario is plausible that Eh was shifted by the development of CY onto ST which had previously grown there. CY, on the other hand, were found at temperatures below $63.2{ }^{\circ} \mathrm{C}$, but only in more oxidized environments with Eh higher than $-112 \mathrm{mV}$. Eh is directly affected by both $\mathrm{DO}$ and hydrogen sulfide concentrations. DO is increased by exposure to air and by photosynthetic activity of cyanobacteria. The hydrogen sulfide concentration decreases as a result of volatilization in flowing effluent and biological oxidation. Hydrogen sulfide must restrict the development of cyanobacterial mats (Castenholtz 1976), whereas ST requires a significant amount of hydrogen sulfide for its growth (Maki 1991). Thus, the hydrogen sulfide concentration can be a major factor controlling the development of both ST and CY. However, as hydrogen sulfide-tolerant and more thermophilic cyanobacteria were not found in the examined Japanese hot springs, temperature, Eh, and DO were shown here to be good indicators and regulators of the boundary environment in flowing systems.

In situ $\mathrm{pH}$ depended on the source of the effluent. Production of $\mathrm{H}_{2} \mathrm{SO}_{4}$ by the 
oxidation of sulfur theoretically decreases the $\mathrm{pH}$ of the environment, and lowering the temperature increases carbon dioxide dissolution, which also decreases $\mathrm{pH}$, but in situ $\mathrm{pH}$ actually tended to increase with the flow of effluent, probably reflecting the oxygen generated by the photosynthetic activity of cyanobacteria (Fig. 5B).

In situ examination revealed that the boundary between ST and CY lay between -112 and $-25 \mathrm{mV}$ Eh (Fig. 5A). The results of the growth experiments, however, showed that sickle-shaped bacteria grew from $\mathrm{Eh}-96$ to $110 \mathrm{mV}$ (Fig. 4). The method used to estimate the growth of sickle-shaped bacteria was primitive and was based on an increase the number of attached cells on a glass slide within a given period. The cell count was confirmed only by cell shape and staining with DAPI, which stains DNA irrespective of species. Thus, whether the increase in cell number on the glass slide could legitimately be ascribed to growth is as yet uncertain. However, no other method is yet available to estimate the in situ growth rate of mat forming thermal chemolithotrophic bacteria that are not yet able to be cultivated. This study may lead the field of extreme microbial ecology from mere findings of existence and the elucidation of phylogeny on the basis of DNA to an understanding of the activity and function of extremophiles in a given ecosystem. The results suggest that sickle-shaped bacteria have the potential to grow in a somewhat more oxidized environment than that observed in situ, although controversy remains concerning the source of hydrogen sulfide and its impact on Eh. After incubation for $12 \mathrm{~h}$, cyanobacterial cells attached to glass slides accounted for less than $8 \%$ of the total number of attached cells. Thus, the effect on the environment of cyanobacterial activity on glass slides proved to be weaker than that found in situ. The experiment suggests that if there is any direct effect of cyanobacteria, sickle-shaped bacteria could develop ST and thus alter the in situ environment. The actual lower boundary of ST was found to be restricted by interaction or competition with cyanobacteria.

Chloroflexus can coexist with both ST and CY (Fig. 2), although BC is also found in 
sites similar to the boundary zone between ST and CY (Fig. 5). The flexible metabolic behavior of Chloroflexus (Pierson and Castenholz 1991) may allow this. On the other hand, ST and CY rarely coexist, although they may be found adjacent to each other. Sickle-shaped bacteria do not construct mats in cyanobacterial habitats, even though they have growth potential within the boundaries of CY. This suggests that an exclusive interaction sustains the boundary between these two ecosystems.

Aquificales, which includes the thermophilic sulfur oxidizer of this study, is widely distributed in geothermal and hydrothermal environments (Reysenbach et al. 2000). Bacteria genetically similar to our sulfur-turf-constructing thermal sulfur oxidizer have been described recently from Iceland (Skirnisdottir et al. 2000), and a candidate similar to ours was previously nominated from Yellowstone National Park (Hugenholtz et al. 1998). We carried out observations and sampling in Yellowstone in 1999 and 2000 and found a genetically similar thermophilic sulfur oxidizer in some sites in Yellowstone. However, it did not form turf but grew as streamers (Yamamoto Hiraishi and Kato, in preparation). The environmental conditions where genetically similar thermophilic sulfur oxidizers were found are summarized in Table 3. All parameters of the hot springs at Yellowstone - temperature, $\mathrm{pH}, \mathrm{Eh}, \mathrm{DO}$, and $\mathrm{H}_{2} \mathrm{~S}$ - overlapped with those of the Japanese hot springs. Measurements in Iceland were also very similar. Thus, temperature and other parameters relevant to the sulfur-oxidizing energy-generating system define clearly the habitat of thermophilic sulfur oxidizers, whether they construct dense mats or appear as hair-like streamers. In addition, if cyanobacterial mats are present, they may restrict the habitat of sulfur-oxidizing bacteria through competition. Under the restricted environmental conditions of chemolithotrophic thermophiles, genetically similar bacteria appear under a certain subset of those conditions. The environment discussed here is, furthermore, presumed to resemble that of the early Archean stage of the evolution of life on Earth (Reysenbach and Cady 2001). 


\section{Acknowledgments}

This study was partly supported by Archaean Park: International Research Project on Interaction between Sub-Vent Biosphere and Geo-Environment (FY2000 to FY2004), funded by the Special Coordination Fund of the Ministry of Education, Culture, Sports, Science and Technology, Japan. Special thanks to Akihiko Maruyama and Tetsuro Urabe, leading scientists of the Archaean Park program, for their encouragement. We thank Aya Kato, Tomoaki Takatsu, and Shizuo Fujiyama of the Department of Biology, Faculty of Science, Shinshu University, for their collaboration. We thank David Word and Thane R. Papke of Montana State University, as well as the office staff of Yellowstone National Park for their kind assistance during our expedition there. We are grateful to S. Higuchi, Nagano Research Institute for Health and Pollution, for his help with sampling and K. Matsuura, Department of Biology, Tokyo Metropolitan University, for useful comments about photosynthetic bacteria. KK should like to dedicate this paper to Dr. Akira Shimizu, former Professor of Nara Women's University. He introduced me to geothermal field where exciting life exists. 


\section{References}

Castenholtz RW. 1976. The effect of sulfide on the bluegreen algae of hot springs. I. New Zealand and Iceland. J Phycol 12:54-68.

Cline JD. 1969. Spectrophotometric determination of hydrogen sulfide in natural waters. Limnol Oceanogr 14:454-458.

Ferris M, Ward DM. 1997. Seasonal distribution of dominant 16S rRNA-defined populations in a hot spring microbial mat examined by denaturing gradient gel electrophoresis. Appl Environ Microbiol 63:1375-1381.

Ferris MJ, Muyzer G, Ward DM. 1996. Denaturing gradient gel electrophoresis profiles of $16 \mathrm{~S}$ rRNA-defined populations inhabiting a hot spring microbial mat community. Appl Environ Microbiol 62:340-346.

Hanada S, Takaichi S, Matsuura K, Nakamura. K. 2002. Roseiflexus castenholzii gen. nov., sp. nov., a thermophilic, filamentous, photosynthetic bacterium that lacks chlorosomes. Int J Syst Evol Microbiol 52:187-193.

Hiraishi A, Umezawa T, Yamamoto H, Kato K, Maki Y. 1999. Changes in quinon profiles of hot spring microbial mats with a thermal gradient. Appl Environ Microbiol 65:198-205.

Hugenholtz P, Pitulle C, Hershberger KL, Pace NR. 1998. Novel division-level bacterial diversity in a Yellowstone hot spring. J Bacteriol 180:366-376.

Knoll AH. 1999. A new molecular window on early life. Science 285:1025-1026

Maki Y. 1986. Factors in habitat preference in situ of sulfur-turfs growing in hot springs effluents: dissolved oxygen and current velocities. J Gen Appl Microbiol 32:203-213.

MakiY. 1987a. Effect of dissolved oxygen concentration on the biological oxidation of 
sulfide and elemental sulfur by the A-type sulfur-turf growing in hot spring effluents. $\mathrm{J}$ Gen Appl Microbiol 33:391-400.

Maki Y. 1987b. Biological oxidation of sulfide and elemental sulfur by the A-type sulfur-turf growing in hot spring effluents. J Gen Appl Microbiol 33:123-134.

Maki Y. 1991. Study of the "sulfur-turf": a community of colorless sulfur bacteria growing in hot spring effluent. Bull Jpn Soc Microb Ecol 6 (1):33-43.

Maki Y. 1993. Rapid biological sulfide oxidation in the effluent of a hot spring. Bull Jpn Soc Microb Ecol 8:175-179.

Pierson BK, Castenholz RW. 1991. The family Chloroflexaceae. In Balows A, Trüper HG, Dworkin M, Harder W, Schleifer KH. (eds.). The Prokaryotes, pp 3754-3774. Springer-Verlag, Berlin, Germany.

Ramsing NB, M. Ferris J, Ward DM. 2000. Highly ordered vertical structure of Synechococcus populations within the one-millimeter thick photic zone of a hot spring cyanobacterial mat. Appl Environ Microbiol 66 (3):1038-1049.

Reysenbach AL, Cady SL. 2001. Microbiology of ancient and modern hydrothermal systems. Trends Microbiol 9 (2):79-86.

Reysenbach AL, Wickham GS, Pace NR. 1994. Phylogenetic analysis of the hyperthermophilic pink filament community in Octopus Spring, Yellowstone National Park. Appl Environ Microbiol 60:2113-2119.

Reysenbach AL, Banta AB, Boone DR, Cary SC, Luther GW. 2000. Microbial essentials at hydrothermal vents. Nature 404:835.

Skirnisdottir S, Hreggvidsson GO, Hjorleifsdottir S, Marteinsson VT, Petursdottir SK, Holst O, Kristjansson JK. 2000. Influence of sulfide and temperature on species composition and community structure of hot spring microbial mats. Appl Environ 
Microbiol 66:2835-2841.

Strickland JDH, Parsons TR. 1972. A practical handbook of sea water analysis. 2nd ed. Bull Fish Res Board Can 167:310

Sugiura M, Takano M, Kawakami S, Toda K, Hanada S. 2001. Application of a portable spectrophotometer to microbial mat studies: temperature dependence of the distribution of cyanobacteria and photosynthetic bacteria in hot spring water. Microbes Environ 16:255-261.

Vargas M, Katei K, Blunt-Harris EL, Loveley DR. 1998. Microbiological evidence for Fe(III) reduction on early Earth. Nature 395:65-67.

Ward DM, Ferris MJ, Nold SC, Bateson MM. 1998. A natural view of microbial biodiversity within hot spring cyanobacterial mat communities. Microbiol Mol Biol Rev 62 (4):1353-1370.

Yamamoto H, Hiraishi A, Kato K, Chiura HX, Maki Y, Shimizu A. 1998. Phylogenetic evidence for the existence of novel thermophilic bacteria in hot spring sulfur-turf microbial mats in Japan. Appl Environ Microbiol 64:1680-1687 
TABLE 1 Environmental parameters of the effluent at the source of each hot spring

\begin{tabular}{|c|c|c|c|c|c|c|c|c|}
\hline Hot spring & Date & $\mathrm{n}$ & $\begin{array}{l}\text { Temperature } \\
\left({ }^{\circ} \mathrm{C}\right)\end{array}$ & $\mathrm{EC}\left(\mathrm{mS} \mathrm{m}^{-1}\right)$ & $\mathrm{pH}$ & $\mathrm{Eh}(\mathrm{mV})$ & $\mathrm{DO}\left(\mathrm{mg} \mathrm{L}^{-1}\right)$ & $\mathrm{S}^{2-}\left(\mathrm{mg} \mathrm{L}^{-1}\right)^{\mathrm{c}}$ \\
\hline \multirow[t]{4}{*}{ Nakafusa } & 1998.10 .9 & 17 & $53.6-62.5$ & $36.4-45.5$ & $8.17-8.44$ & $-136--52$ & $0.42-1.66$ & $2-3$ \\
\hline & 1998.10 .16 & 17 & $51.8-64.9$ & $36.8-48.9$ & $8.00-8.18$ & $-116--40$ & $0.39-1.47$ & $2.5-3$ \\
\hline & 1998.10 .23 & 13 & $55.8-64.5$ & $31.8-34.2$ & $8.17-8.26$ & $-82-+11$ & $0.47-1.43$ & $\mathrm{ND}^{\mathrm{b}}$ \\
\hline & 1998.10 .30 & 13 & $52.8-59.2$ & $40.0-44.8$ & $8.28-8.36$ & $-111--17$ & $0.35-1.45$ & 2 \\
\hline \multirow[t]{2}{*}{ Nakanoyu } & 1998.5.9 & 1 & $83.6-85.1$ & $102.8-106.4$ & 6.52 & $-205--195$ & $0.22-0.27$ & 6 \\
\hline & 1998.11 .12 & 1 & 89.2 & 105 & 6.22 & -180 & $\mathrm{BD}^{\mathrm{a}}$ & 10 \\
\hline Yumata & 1998.8.27 & 1 & 79.7 & 183.7 & 6.31 & -170 & $\mathrm{BD}^{\mathrm{a}}$ & 25 \\
\hline
\end{tabular}

${ }^{\mathrm{a}}$ Below detection limit.

${ }^{\mathrm{b}}$ No data.

${ }^{\mathrm{c}}$ Determined with a simple tube kit

TABLE 2 Environmental constraints on the different microbial mats at Japanese hot springs

\begin{tabular}{|c|c|c|c|c|c|c|c|c|}
\hline \multirow[b]{2}{*}{ Mat type } & \multicolumn{5}{|c|}{ Range of environmental parameters for 4 mat types } & \multicolumn{3}{|c|}{$\begin{array}{c}\text { Appearance of } 4 \text { mat types in } 3 \text { examined } \\
\text { hot springs }{ }^{\mathrm{a}}\end{array}$} \\
\hline & $\begin{array}{c}\text { Temperature } \\
\left({ }^{\circ} \mathrm{C}\right)\end{array}$ & $\mathrm{pH}$ & $\mathrm{EC}\left(\mathrm{mS} \mathrm{m}^{-1}\right)$ & Eh $(\mathrm{mV})$ & $\mathrm{DO}\left(\mathrm{mg} \mathrm{L}^{-1}\right)$ & Nakafusa & Nakanoyu & Yumata \\
\hline $\begin{array}{l}\text { Sulfur-turf } \\
\text { (ST) }\end{array}$ & $51.1-77.2$ & $6.45-8.41$ & $36.4-181.4$ & $-205--25$ & $<1.81$ & + & ++ & ++ \\
\hline $\begin{array}{l}\text { Cyanobacterial mat } \\
\text { (CY) }\end{array}$ & $40.0-63.2$ & $7.53-8.48$ & $27.0-133.7$ & $-112-+173$ & $0.25-5.25$ & ++ & ++ & + \\
\hline $\begin{array}{l}\text { Bacteriochlorophyll c - } \\
\text { containing mats } \\
\text { (BC) }\end{array}$ & $53.5-60.3$ & $7.73-7.94$ & $164.7-174.3$ & $-143--89$ & $0.49-2.02$ & - & - & ++ \\
\hline $\begin{array}{l}\text { Purple colored mat } \\
\qquad \text { (PM) }\end{array}$ & 48.8 & 7.71 & 104.1 & -67 & 1.85 & - & + & - \\
\hline
\end{tabular}

${ }^{a}++$, the mat existed in a wide region. + , the mat existed in a limited region. - , the mat did not exist. 
TABLE 3 Comparison of three environments where colorless sulfur bacteria have been found

\begin{tabular}{cccccc}
\hline Hot spring & $\begin{array}{c}\text { Temperature } \\
\left({ }^{\circ} \mathrm{C}\right)\end{array}$ & $\mathrm{pH}$ & $\mathrm{Eh}(\mathrm{mV})$ & $\mathrm{DO}\left(\mathrm{mg} \mathrm{L}^{-1}\right)$ & $\mathrm{H}_{2} \mathrm{~S}\left(\mathrm{mg} \mathrm{L}^{-1}\right)$ \\
\hline Japanese hot springs & $51.1-77.2$ & $6.45-8.41$ & $-205--25$ & $<1.81$ & $0.07-9.37^{\mathrm{b}}$ \\
Yellowstone & $58.1-72.3$ & $6.19-7.62$ & $-133--59$ & $0.35-1.59$ & $<10.6^{\mathrm{b}}$ \\
$\begin{array}{c}\text { Iceland (Skirnisdottir } \\
\text { et al. 2000) }\end{array}$ & 67 & 6.7 & $\mathrm{ND}^{\mathrm{a}}$ & $\mathrm{ND}^{\mathrm{a}}$ & $12^{\mathrm{c}}$ \\
\hline
\end{tabular}

${ }^{\text {a No data. }}$

${ }^{\mathrm{b}}$ Determined by spectrophotometry

${ }^{\mathrm{c}}$ Determined by mercury acetate titration 


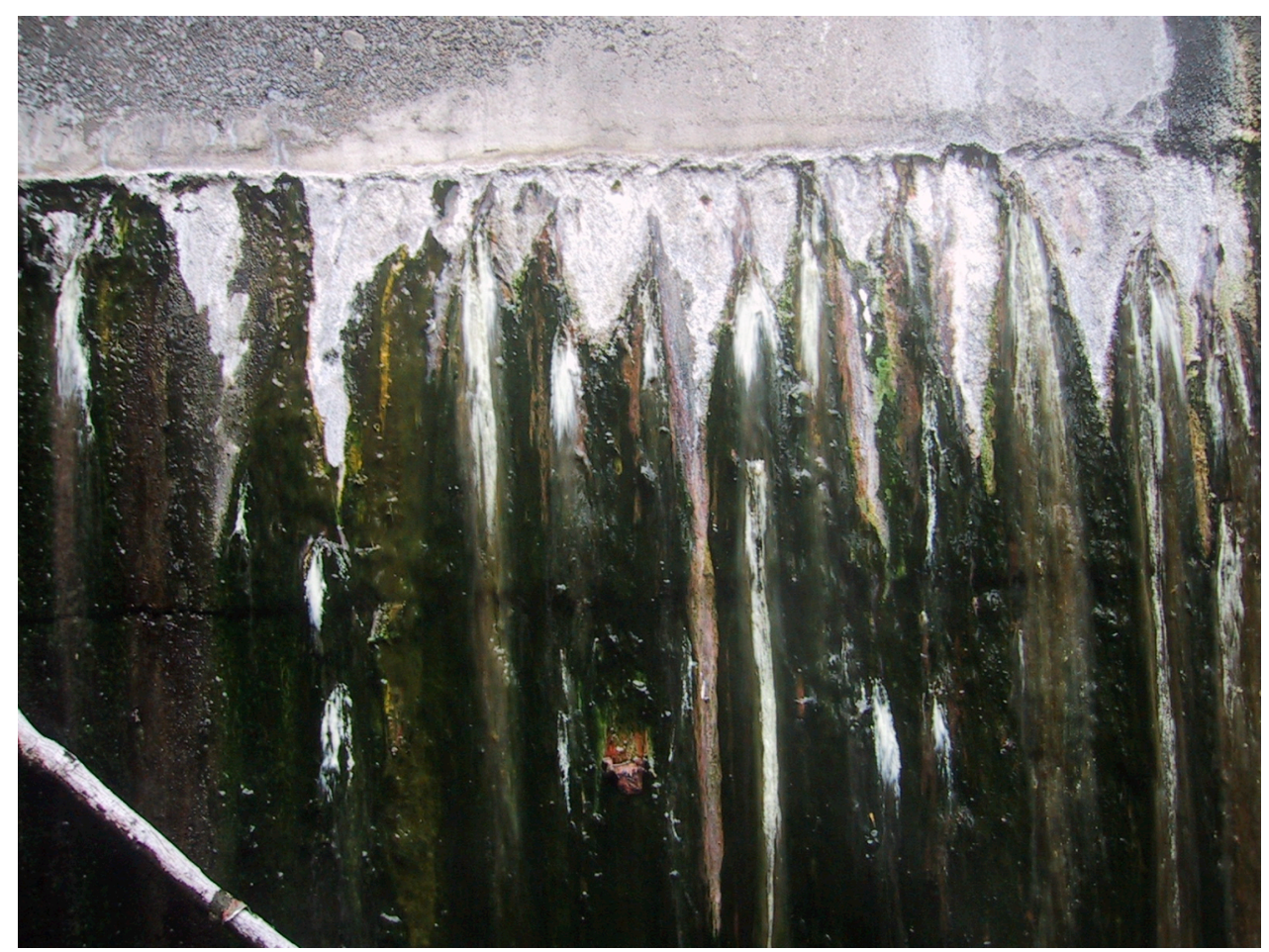

Figure 1. Co-existence of sulfur-turf (ST; white) and cyanobacterial mats (CY; dark green) with distinct boundaries between them on the wall of a debris dam at Nakafusa hot springs. ST growth is initiated at several points where sulfide rich effluent flows from horizontal cracks. The white ST is about $10 \mathrm{~cm}$ wide. 


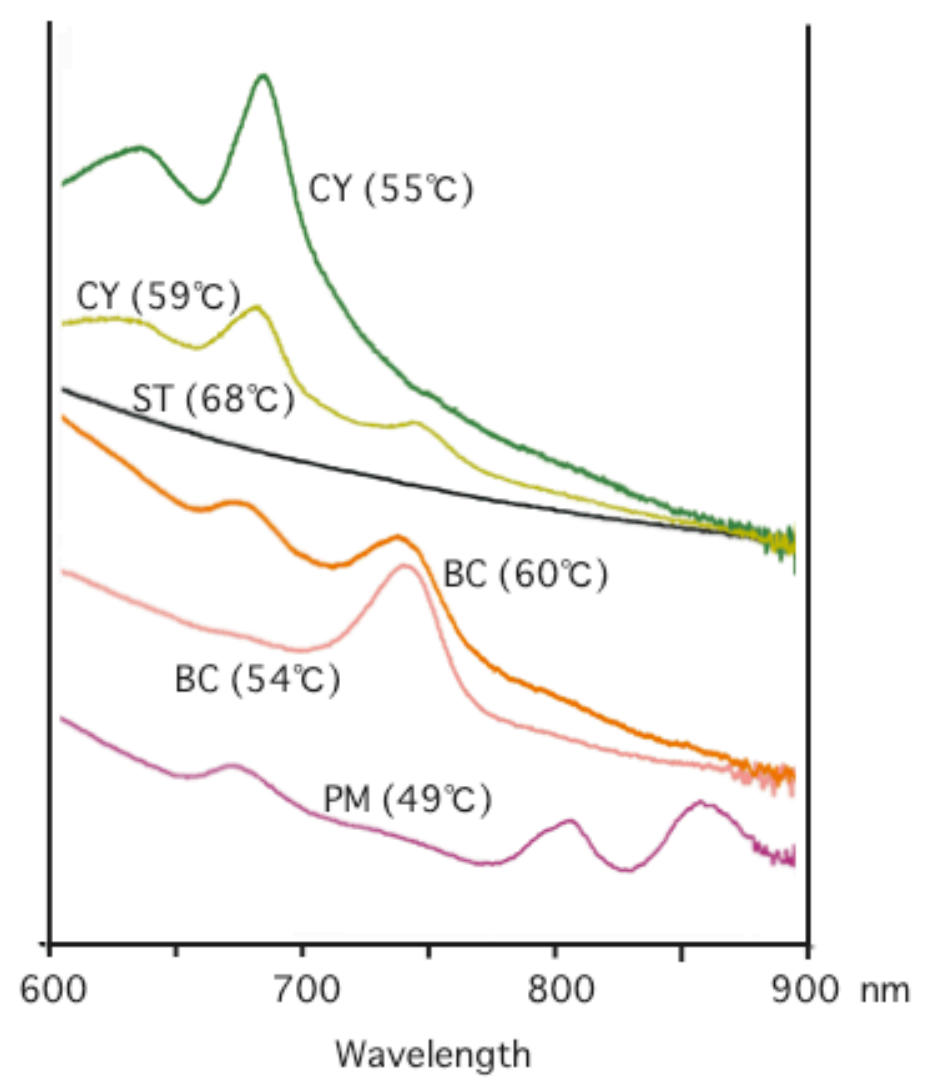

Figure 2. Absorption spectra of hot spring microbial mats. $\mathrm{CY}\left(55^{\circ} \mathrm{C}\right)$, cyanobacterial mat growing at $55^{\circ} \mathrm{C}$ at Nakafusa hot spring. $\mathrm{CY}\left(59^{\circ} \mathrm{C}\right)$, cyanobacterial mat growing at $59{ }^{\circ} \mathrm{C}$ at Nakafusa hot spring; ST $\left(68^{\circ} \mathrm{C}\right)$, sulfur-turf growing at $68^{\circ} \mathrm{C}$ at Yumata hot spring; $\mathrm{BC}\left(60^{\circ} \mathrm{C}\right)$, bacteriochlorophyll $c$-containing mat growing at $60^{\circ} \mathrm{C}$ at Yumata hot spring; $\mathrm{BC}\left(54{ }^{\circ} \mathrm{C}\right)$, bacteriochlorophyll $c$-containing mat growing at $54{ }^{\circ} \mathrm{C}$ at Yumata hot spring; $\mathrm{PM}\left(49^{\circ} \mathrm{C}\right)$, purple mat growing at $49^{\circ} \mathrm{C}$ at Nakanoyu hot spring. 


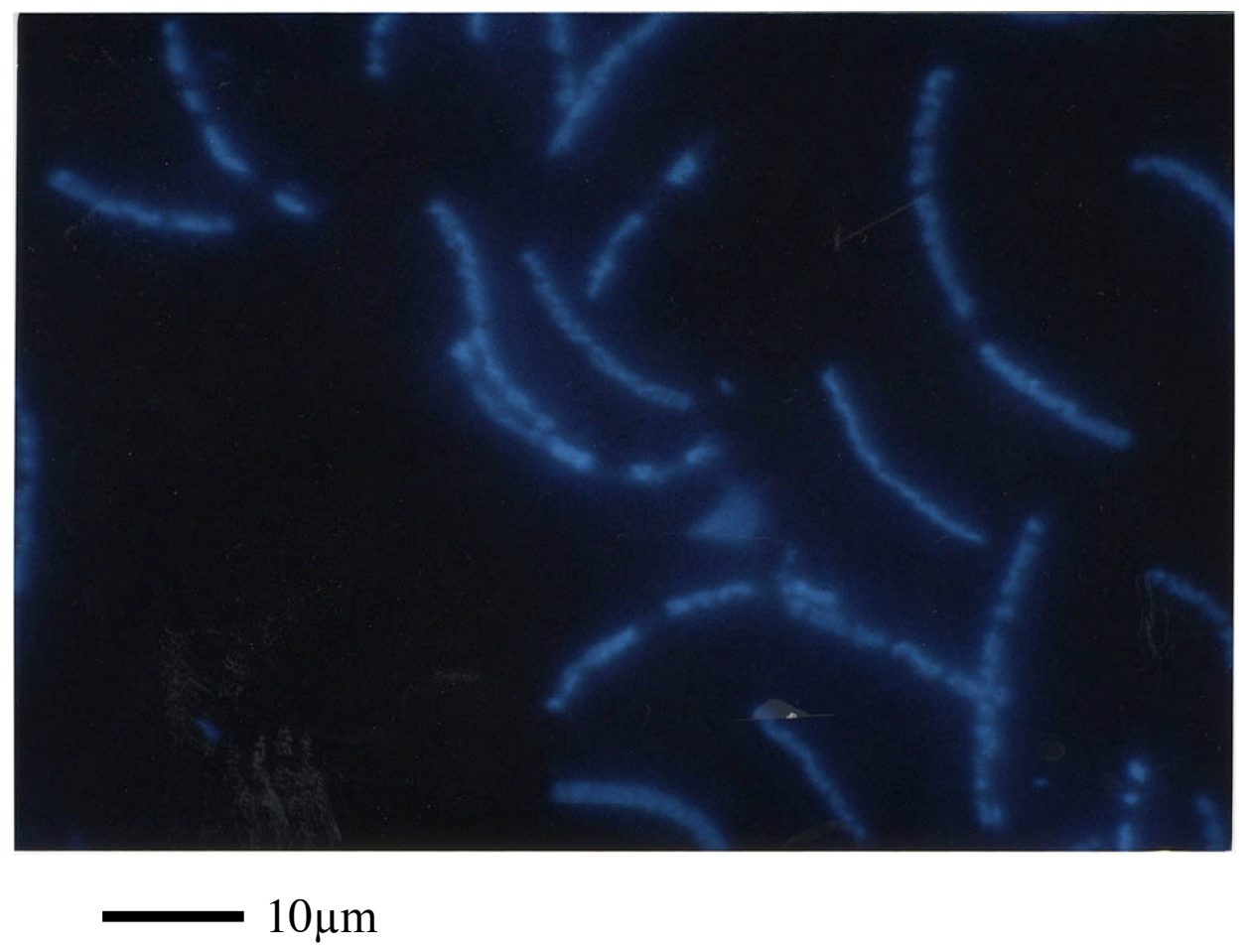

Figure 3. Epifluorescence microscopic image of large sickle-shaped bacteria stained with 4',6-diamidino-2-phenylindole (DAPI). Length of cells is about $20 \mu \mathrm{m}$. 

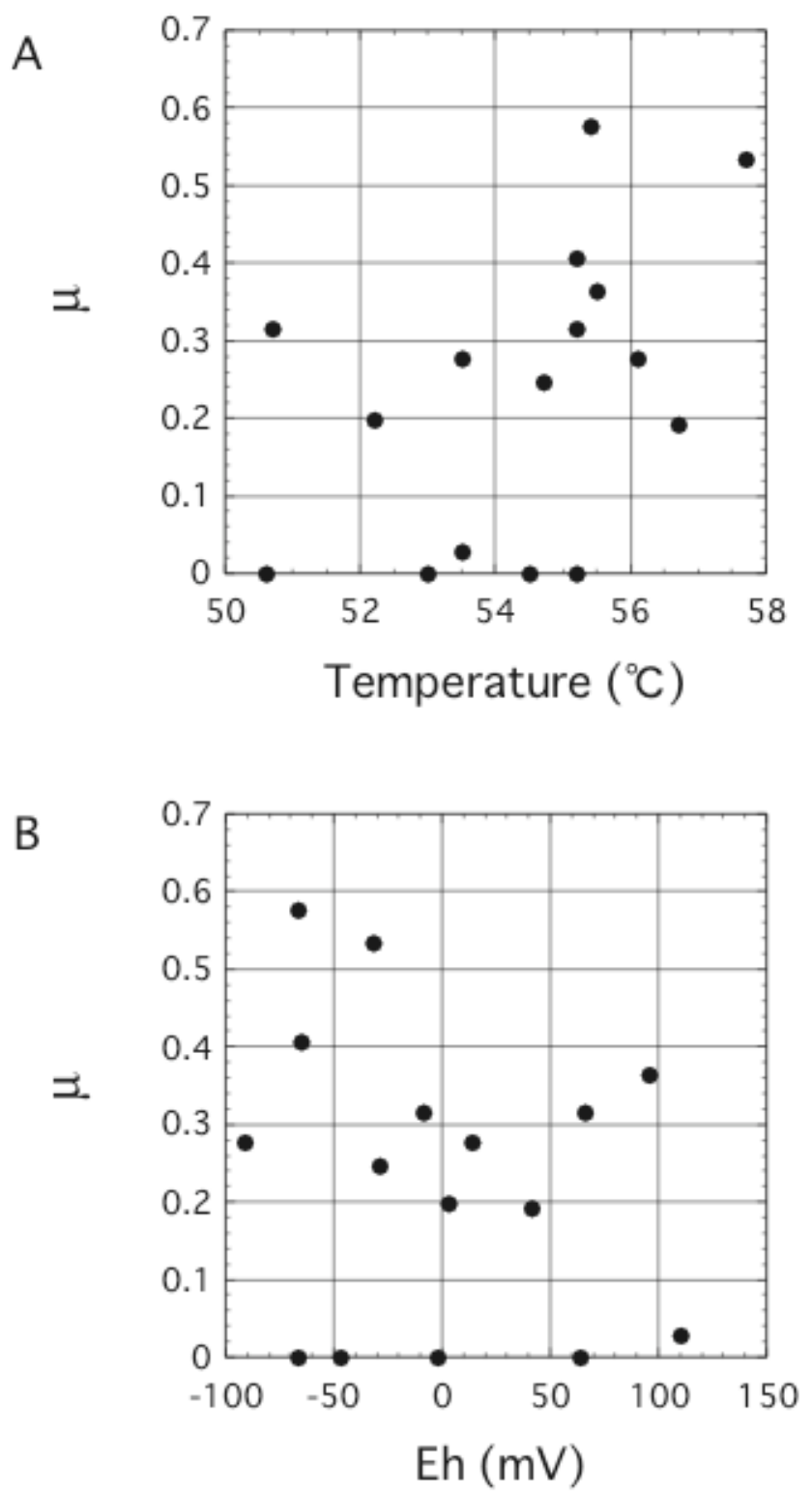

Figure 4. Estimated growth rate constant $(\mu)$ of sickle-shaped bacteria compared with temperature (A) and Eh (B). 

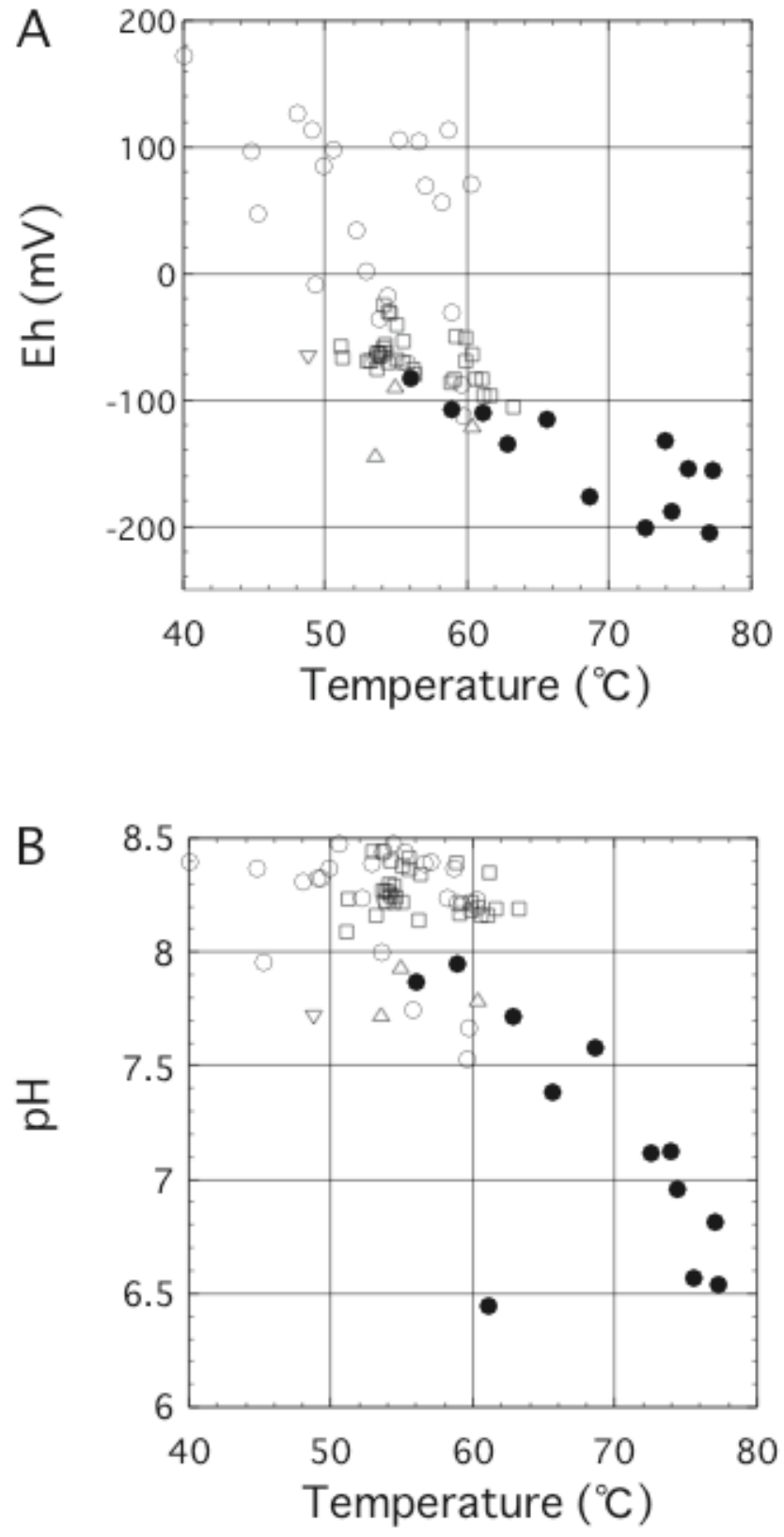


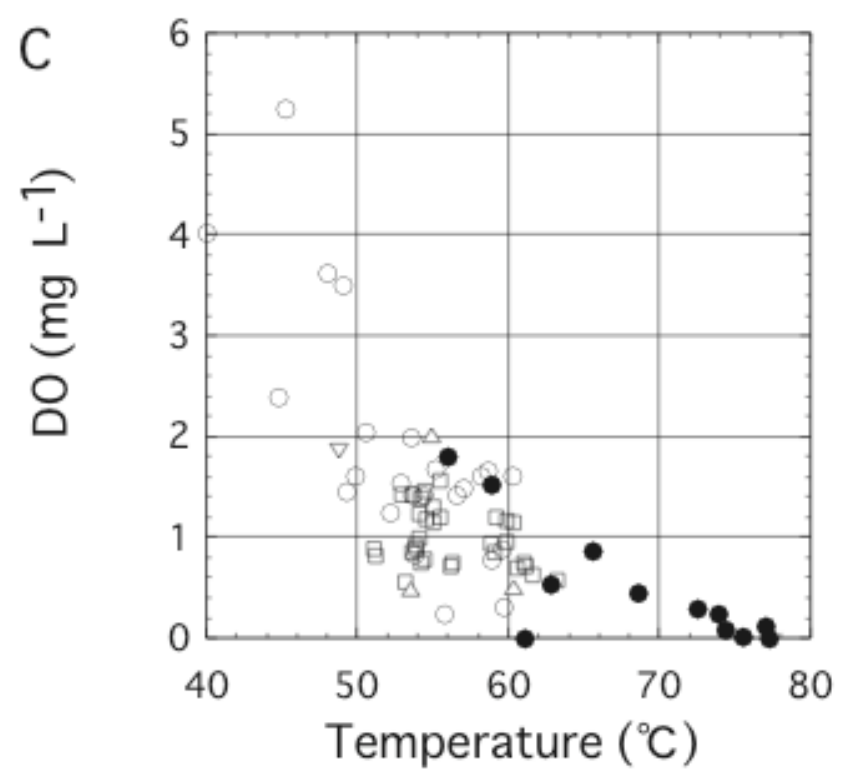

Figure 5. Distribution of microbial mats in the Japanese hot spring effluents examined. Distribution is shown in relation to (A) temperature-Eh, (B) temperature- $\mathrm{pH}$, and (C) temperature - dissolved oxygen (DO). $\bigcirc$, sulfur-turf (ST, $n=12$ ); $\bigcirc$; cyanobacterial mat (CY, $n=24) ; \triangle$, bacteriochlorophyll $c$-containing microbial mats (BC, $n=3)$. $\nabla$; purple microbial mat (PM, $n=1)$; $\square$, zone of coexistence of ST and CY at Nakafusa hot spring $(n=32)$. 